|

Gasbuggy, New Mexico, Hydrologic and Natural Gas Sampling and Analysis Results for 2009

November 2009

Approved for public release; further dissemination is unlimited 
Available for sale to the public from:

U.S. Department of Commerce

National Technical Information Service

5301 Shawnee Road

Alexandria, VA 22312

Telephone: 800.553.6847

Fax: 703.605.6900

E-mail: orders@ntis.gov

Online Ordering: http://www.ntis.gov/help/ordermethods.aspx

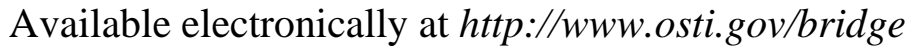

Available for a processing fee to U.S. Department of Energy and its contractors, in paper, from:

U.S. Department of Energy

Office of Scientific and Technical Information

P.O. Box 62

Oak Ridge, TN 37831-0062

Phone: 865.576.8401

Fax: 865.576.5728

Email: reports@adonis.osti.gov

Reference herein to any specific commercial product, process, or service by trade name, trademark, manufacturer, or otherwise, does not necessarily constitute or imply its endorsement, recommendation, or favoring by the United States Government or any agency thereof or its contractors or subcontractors. 


\section{Gasbuggy, New Mexico, Hydrologic and Natural Gas Sampling and Analysis Results for 2009}

November 2009

Approved for public release; further dissemination is unlimited 
This page intentionally left blank 


\section{Contents}

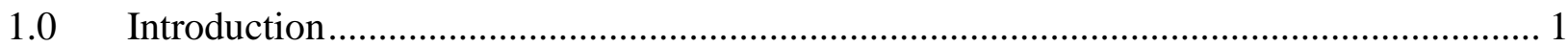

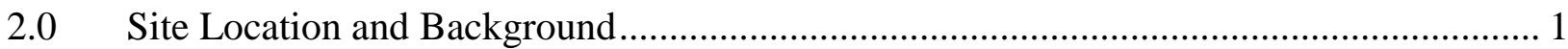

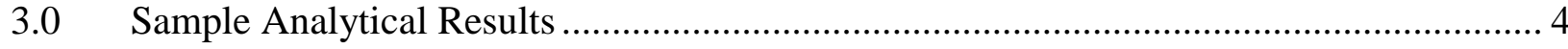

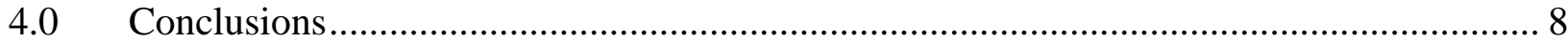

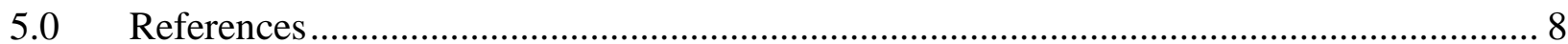

\section{Figures}

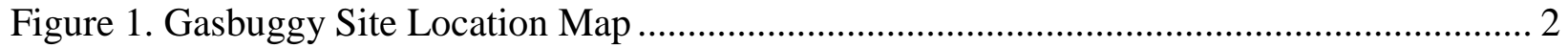

Figure 2. Hydrologic Monitoring Locations .................................................................. 3

Figure 3. Groundwater Tritium Concentration ....................................................................... 5

Figure 4. Surface Water Tritium Concentration ................................................................... 6

\section{Tables}

Table 1. Gasbuggy Hydrologic Sample Analysis Results ................................................... 4

Table 2. Gasbuggy Natural Gas Production Well Produced Water Sample Analysis Results ....... 7

Table 3. Gasbuggy Natural Gas Production Well Gas Sample Analysis Results......................... 7 
This page intentionally left blank 


\subsection{Introduction}

The U.S. Department of Energy (DOE) Office of Legacy Management conducted hydrologic and natural gas sampling for the Gasbuggy, New Mexico, site on June 16, and 17, 2009. Hydrologic sampling consists of collecting water samples from water wells and surface water locations. Natural gas sampling consists of collecting both gas samples and samples of produced water from gas production wells. The water well samples were analyzed for gamma-emitting radionuclides and tritium. Surface water samples were analyzed for tritium. Water samples from gas production wells were analyzed for gamma-emitting radionuclides, gross alpha, gross beta, and tritium. Natural gas samples were analyzed for tritium and carbon-14. Water samples were analyzed by ALS Laboratory Group in Fort Collins, Colorado, and natural gas samples were analyzed by Isotech Laboratories in Champaign, Illinois.

\subsection{Site Location and Background}

The Gasbuggy site comprises 640 acres in Rio Arriba County, New Mexico, approximately 55 miles east of the city of Farmington and approximately 21 miles southwest of the town of Dulce, in the Carson National Forest (see Figure 1). One underground nuclear detonation was conducted at the Gasbuggy site on December 10, 1967, in an effort to stimulate natural gas production in the gas-bearing Pictured Cliffs Formation. The detonation took place at a depth of 4,240 feet below ground surface, approximately 40 feet below the Pictured Cliffs Sandstone/Lewis Shale contact. The detonation had an estimated yield of 29 kilotons.

Locations for this sampling event included off-site springs and other surface waters, wells, and off-site natural gas production wells. There are no wells, springs, surface water, or gas wells on site. Water sample locations (see Figure 2) range from approximately 3 to 7 miles from the emplacement hole. Water well depths range from 75 feet to 229 feet below ground surface.

Gas sample locations (see attached map) range from 1 mile to 1.7 miles from the emplacement hole. Seven of the eight gas wells sampled are perforated for gas production from the Pictured Cliffs Formation, the same formation targeted by the Gasbuggy test. The eighth gas well sampled is perforated for production from the Gallup Formation, approximately 3,000 feet deeper than the Gasbuggy detonation point and the Pictured Cliffs Formation.

The U.S. Environmental Protection Agency performed water sampling at the water wells, springs, and ponds from the inception of the Hydrologic Monitoring Program in 1972 through 2007. DOE's Office of Legacy Management has performed the hydrologic sampling at these locations since 2007. Sampling of natural gas and produced water from nearby producing gas wells was conducted for the first time during the 2009 sampling event. 


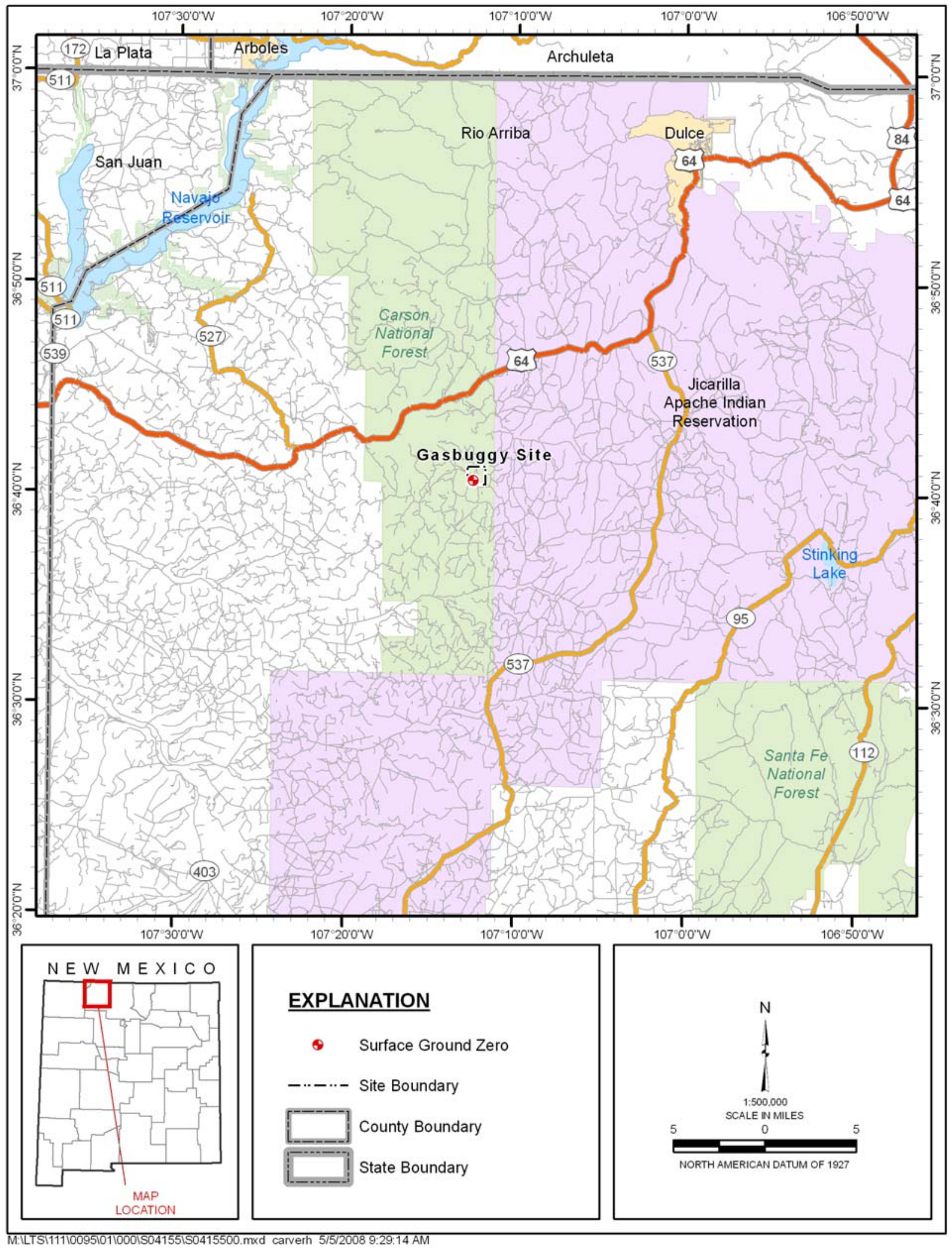

Figure 1. Gasbuggy Site Location Map 


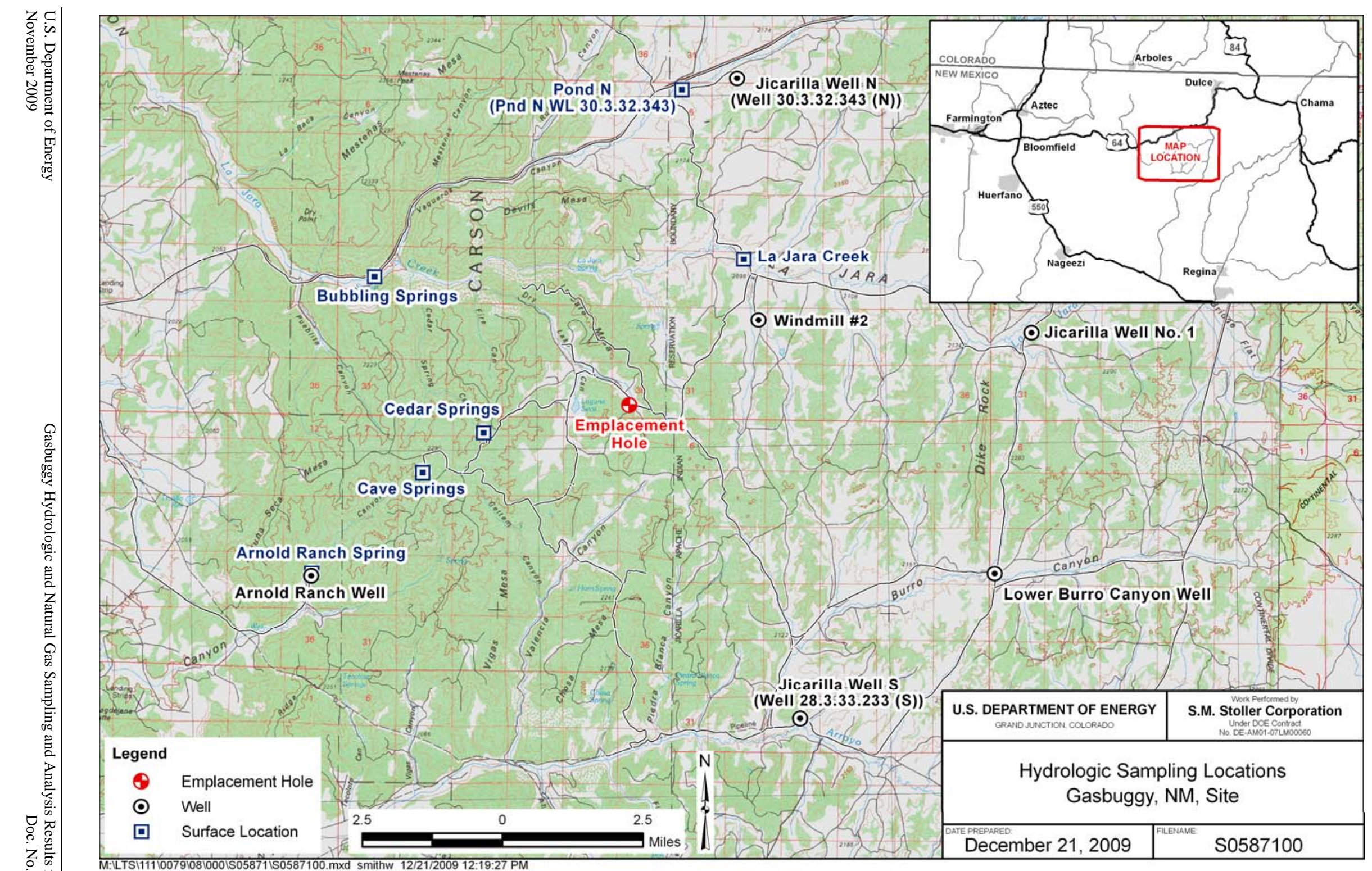

Figure 2. Hydrologic Monitoring Locations 
Results of the historical hydrologic monitoring at Gasbuggy have consistently shown that groundwater and surface water at the sample locations have not been affected by radionuclides from the nuclear test (see Figures 3 and 4 for historical tritium sample analysis results). DOE recently completed an evaluation of the Hydrologic Monitoring Program and concluded that the water sample locations were too shallow and too far from emplacement hole to realistically be impacted by detonation-related contaminants (DOE 2009), and annual hydrologic monitoring was no longer justified. Since nearby gas wells that are producing gas from the same formation affected by the Gasbuggy test represent a more feasible contaminant migration pathway, DOE began sampling gas wells. Henceforth, DOE will sample natural gas production wells annually, and hydrologic monitoring will be conducted once every 5 years.

\subsection{Sample Analytical Results}

Analytical results from the June 16-17, 2009, sampling event are shown in Tables 1, 2, and 3. Tritium, the most mobile detonation-related contaminant, was not detected in any of the water or natural gas samples. Potassium-40 was detected in water from Jicarilla Well N, and uranium-235 was detected in water from Jicarilla Well No. 1. In both cases the reported concentrations are considered estimated values, because they were less than three times the method detection limit. ${ }^{1}$ These constituents occur naturally in the environment, and the estimated concentrations are reasonable for naturally occurring background levels. Table 1 shows the groundwater and surface water sample analytical results.

Table 1. Gasbuggy Hydrologic Sample Analysis Results

\begin{tabular}{||l|c|c|c||}
\hline \multicolumn{1}{|c|}{ Sample Location } & Collection Date & $\begin{array}{c}\text { Tritium } \\
\text { (pCi/L) }\end{array}$ & $\begin{array}{c}\text { Gamma Spectroscopy } \\
\text { (pCi/L) }\end{array}$ \\
\hline Arnold Ranch Well & Not sampled_resident not home & NA & NA \\
\hline Arnold Ranch Spring & Not sampled_resident not home & NA & NA \\
\hline Bubbling Springs & Not sampled_dry & NA & NA \\
\hline Cave Springs & $06 / 17 / 2009$ & ND & NA \\
\hline Cedar Springs & $06 / 17 / 2009$ & ND & ND \\
\hline Jicarilla Well N & $06 / 16 / 2009$ & ND & ND \\
\hline Jicarilla Well S & $06 / 16 / 2009$ & ND & $13.5^{\text {a }}$ (uranium-235) \\
\hline Jicarilla Well No. 1 & $06 / 16 / 2009$ & ND & NA \\
\hline La Jara Creek & $06 / 16 / 2009$ & ND & ND \\
\hline Lower Burro Canyon Well & $06 / 16 / 2009$ & ND & NA \\
\hline Pond N & $06 / 16 / 2009$ & ND & ND \\
\hline Windmill \#2 & $06 / 16 / 2009$ & & Nam \\
\hline
\end{tabular}

${ }^{\mathrm{a}}$ Estimated value.

$\mathrm{pCi} / \mathrm{L}=$ picocuries per liter

$\mathrm{ND}=$ Result below laboratory method detection limit.

$\mathrm{NA}=$ Not analyzed .

\footnotetext{
${ }^{1}$ When a reported radionuclide concentration is less than three times the method detection limit the result is considered an estimated value because of the high degree of uncertainty associated with very low measured concentrations.
} 


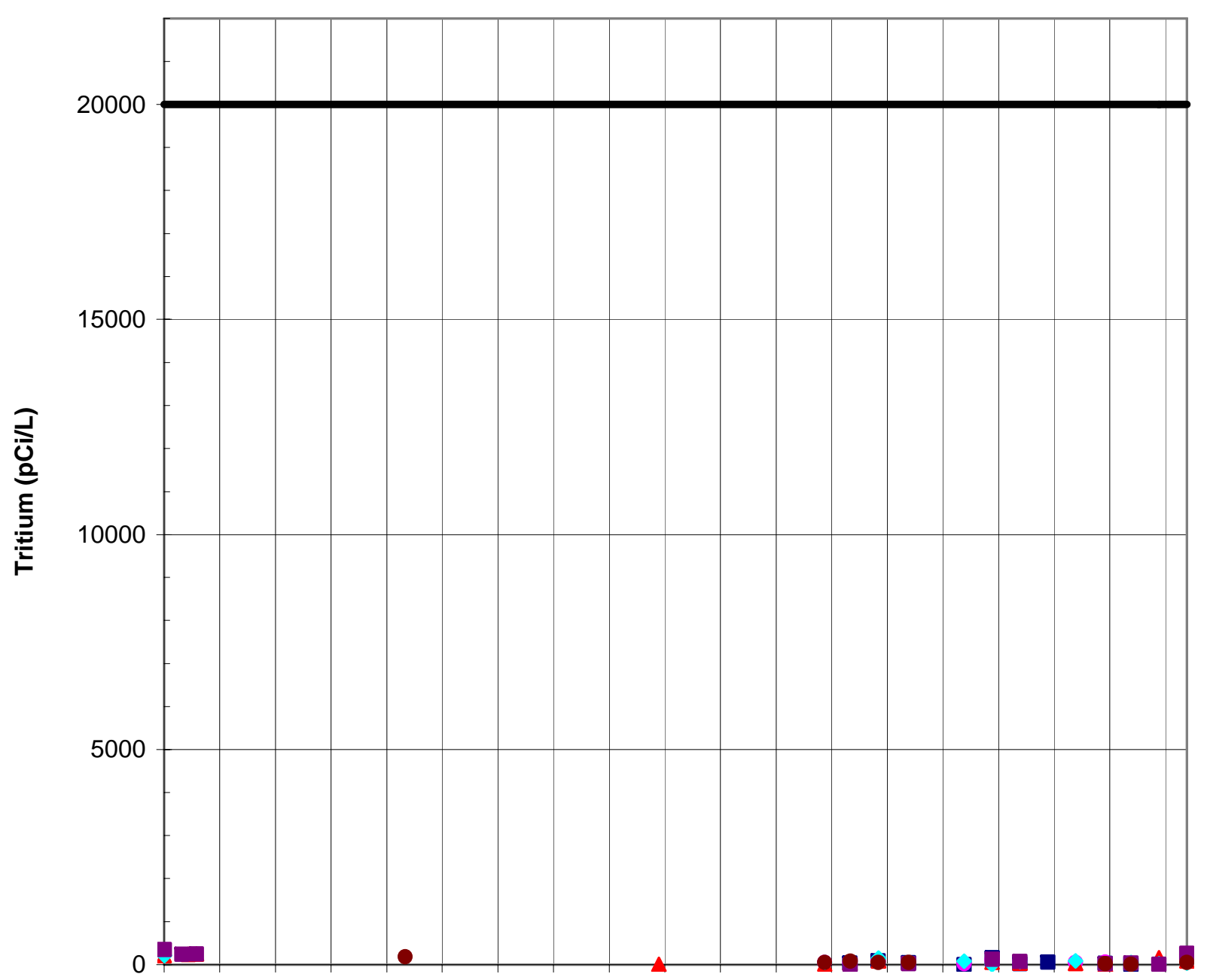

- Arnold Ranch Well

- Jicarilla Well 1

- Lower Burro Canyon

- Jicarilla Well S

- Jicarilla Well N

- Windmill \#2

EPA Drinking Water Standard

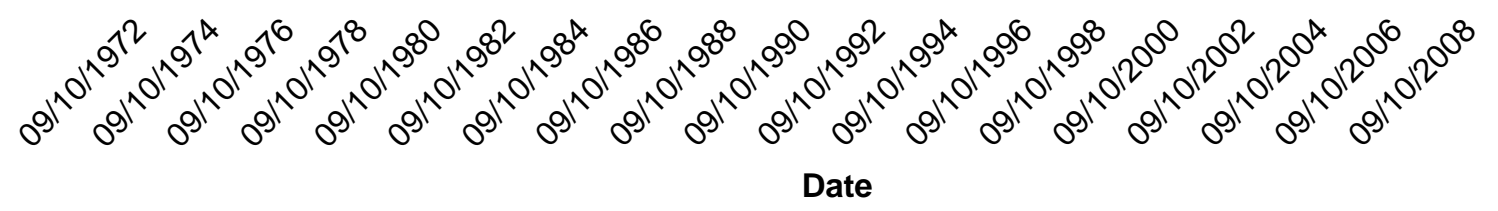

Figure 3. Groundwater Tritium Concentration 


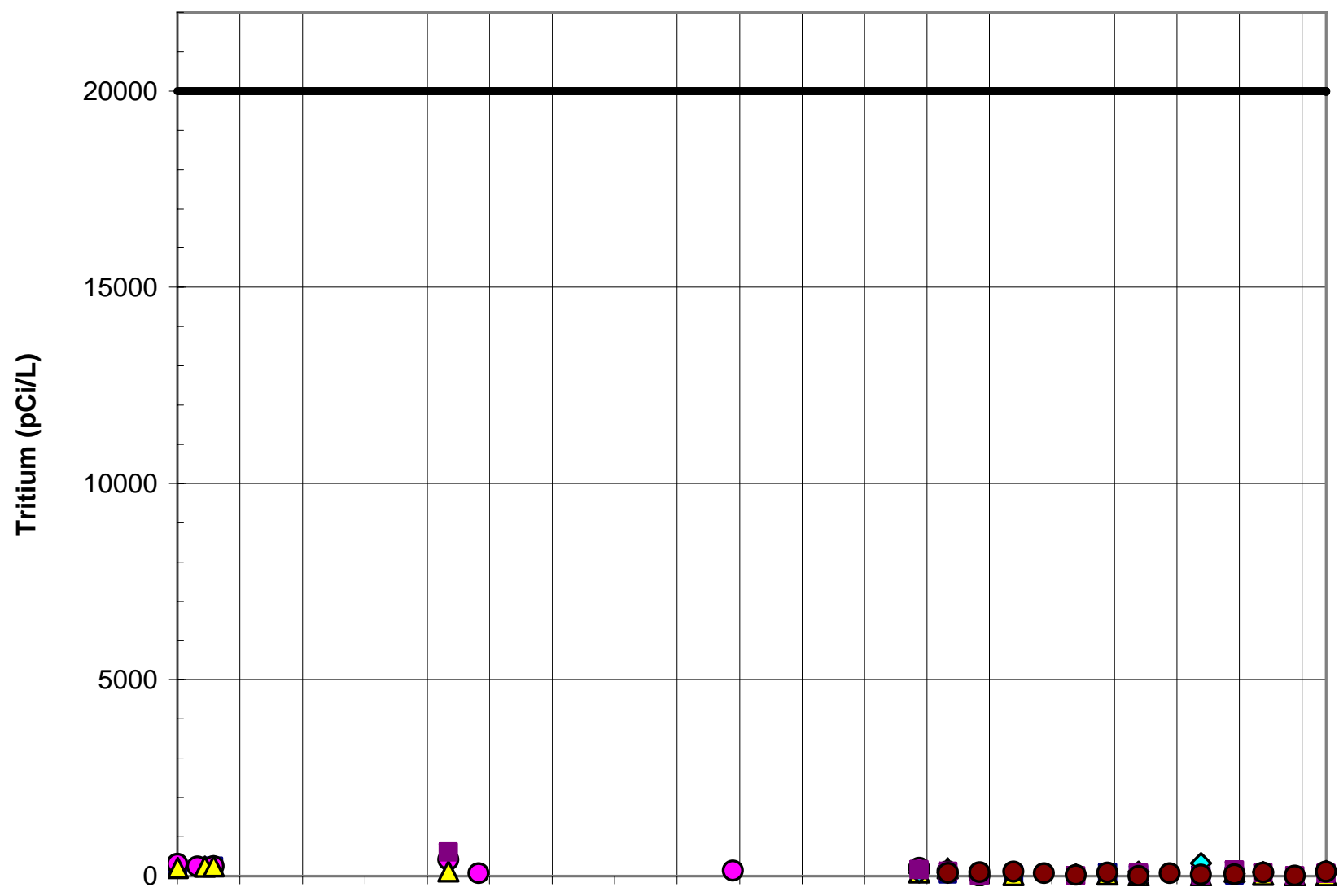

- Arnold Ranch Spring

- Bubbling Springs

$\Delta$ Cave Springs

$\diamond$ Cedar Springs

- La Jara Creek

- Pond $\mathrm{N}$

EPA Drinking Water Standard

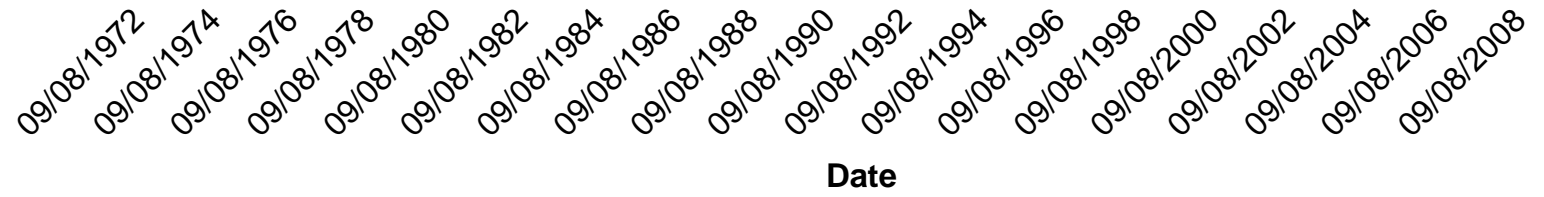

Figure 4. Surface Water Tritium Concentration 
Table 2. Gasbuggy Natural Gas Production Well Produced Water Sample Analysis Results

\begin{tabular}{||l|c|c|c|c|c||}
\hline \multicolumn{1}{|c|}{$\begin{array}{c}\text { Sample Location } \\
\text { (API \#) }\end{array}$} & $\begin{array}{c}\text { Collection } \\
\text { Date }\end{array}$ & $\begin{array}{c}\text { Tritium } \\
\text { (pCi/L) }\end{array}$ & $\begin{array}{c}\text { Gamma } \\
\text { Spectroscopy } \\
\text { (pCi/L) }\end{array}$ & $\begin{array}{c}\text { Gross } \\
\text { Alpha } \\
(\mathbf{p C i} / \mathbf{L})\end{array}$ & $\begin{array}{c}\text { Gross } \\
\text { Beta } \\
\text { (pCi/L) }\end{array}$ \\
\hline $\begin{array}{l}\text { Indian A No. 002 } \\
(30-039-07525)\end{array}$ & $06 / 17 / 2009$ & ND & ND & ND & ND \\
\hline $\begin{array}{l}\text { Jicarilla 28-3 No. 001 } \\
(30-039-21097)\end{array}$ & $06 / 17 / 2009$ & ND & NA & ND & ND \\
\hline $\begin{array}{l}\text { Many Canyons 29-04-25 No. 123 } \\
(30-039-30161)\end{array}$ & $06 / 17 / 2009$ & ND & ND & ND & ND \\
\hline $\begin{array}{l}\text { Many Canyons 29-04-26 No. 133 } \\
(30-039-29988)\end{array}$ & $06 / 17 / 2009$ & ND & ND & ND & $39.1^{\text {a }}$ \\
\hline $\begin{array}{l}\text { Schalk 29-4 No. 007 } \\
(30-039-21620)\end{array}$ & $06 / 17 / 2009$ & ND & ND & ND & 30.1 \\
\hline $\begin{array}{l}\text { Schalk 29-4 No. 014 } \\
(30-039-21744)\end{array}$ & $06 / 17 / 2009$ & ND & ND & ND & ND \\
\hline $\begin{array}{l}\text { Schalk 29-4 No. 017 } \\
(30-039-21743)\end{array}$ & $06 / 17 / 2009$ & ND & ND & ND & ND \\
\hline $\begin{array}{l}\text { Valencia Canyon Unit No. 037 } \\
(30-039-21647)\end{array}$ & $06 / 17 / 2009$ & ND & ND & ND & $37.7^{a}$ \\
\hline
\end{tabular}

${ }^{\mathrm{a}}$ Estimated value.

$\mathrm{pCi} / \mathrm{L}=$ picocuries per liter

$\mathrm{ND}=$ Result below laboratory method detection limit.

$\mathrm{NA}=$ Not analyzed.

Table 3. Gasbuggy Natural Gas Production Well Gas Sample Analysis Results

\begin{tabular}{||l|c|c|c||}
\hline \multicolumn{1}{|c|}{$\begin{array}{c}\text { Sample Location } \\
\text { (API \#) }\end{array}$} & Collection Date & $\begin{array}{c}\text { Tritium } \\
(\mathbf{p C i} / \mathbf{L})\end{array}$ & $\begin{array}{c}\text { Carbon-14 } \\
\text { (pCi/L) }\end{array}$ \\
\hline $\begin{array}{l}\text { Indian A No. 002 } \\
(30-039-07525)\end{array}$ & $06 / 17 / 2009$ & ND & 0.016 \\
\hline $\begin{array}{l}\text { Jicarilla 28-3 No. 001 } \\
(30-039-21097)\end{array}$ & $06 / 17 / 2009$ & ND & 0.043 \\
\hline $\begin{array}{l}\text { Many Canyons 29-04-25 No. 123 } \\
(30-039-30161)\end{array}$ & $06 / 17 / 2009$ & ND & ND \\
\hline $\begin{array}{l}\text { Many Canyons 29-04-26 No. 133 } \\
(30-039-29988)\end{array}$ & $06 / 17 / 2009$ & ND & ND \\
\hline $\begin{array}{l}\text { Schalk 29-4 No. 007 } \\
(30-039-21620)\end{array}$ & $06 / 17 / 2009$ & ND & ND \\
\hline $\begin{array}{l}\text { Schalk 29-4 No. 014 } \\
(30-039-21744)\end{array}$ & $06 / 17 / 2009$ & ND & 0.013 \\
\hline $\begin{array}{l}\text { Schalk 29-4 No. 017 } \\
(30-039-21743)\end{array}$ & $06 / 17 / 2009$ & ND & ND \\
\hline $\begin{array}{l}\text { Valencia Canyon Unit No. 037 } \\
(30-039-21647)\end{array}$ & $06 / 17 / 2009$ & ND & 0.019 \\
\hline
\end{tabular}

$\mathrm{ND}=$ Result below laboratory method detection limit.

Concentrations are in picocuries per liter $(\mathrm{pCi} / \mathrm{L})$ of methane.

Low levels of gross beta activity were detected in samples of produced water from three of the natural gas production wells; two of the results were estimated values. The low levels are representative of natural background radioactivity and do not indicate the presence of detonationrelated radionuclides. Refer to Table 2 for produced water sample analytical results. 
Low concentrations of carbon-14 were detected in four of the natural gas samples. These concentrations, ranging from 0.013 to 0.043 picocuries per liter $(\mathrm{pCi} / \mathrm{L})$, are most likely attributed to evaporation of water in the formation that was introduced during drilling or the well development process. For comparison, carbon-14 concentrations measured in the gas produced from the Gasbuggy chimney after the detonation (Tewes 1979) were on the order of 1,000 pCi/L, five orders of magnitude greater than the currently detected concentrations. This indicates that the carbon-14 detected in neighboring gas wells is not associated with the detonation. Refer to Table 3 for natural gas sample analytical results.

\subsection{Conclusions}

Concentrations of tritium and gamma-emitting radionuclides in water samples collected in the vicinity of the Gasbuggy site continue to demonstrate that the sample locations have not been impacted by detonation-related contaminants. Results from the sampling of natural gas from producing wells demonstrate that the gas wells nearest the Gasbuggy site are not currently impacted by detonation-related contaminants. Annual sampling of the gas production wells nearest the Gasbuggy site for gas and produced water will continue for the foreseeable future. The sampling frequency of water wells and surface water sources in the surrounding area will be reduced to once every 5 years. The next hydrologic sampling event at water wells, springs, and ponds will be in 2014.

\subsection{References}

DOE (U.S. Department of Energy), 2009. Gasbuggy, New Mexico Long-Term Hydrologic Monitoring Program Evaluation Report, LMS/GSB/S04019, Office of Legacy Management, Grand Junction, CO, June.

Tewes, Howard A., 1979. Survey of Gas Quality Results from Three Gas-Well-Stimulation Experiments by Nuclear Explosions, Lawrence Livermore Laboratory, UCRL-52656, January 23. 


\section{Library Distribution List}

U.S. Department of Energy

National Nuclear Security Administration

Nevada Site Office

Technical Library

P.O. Box 98518, M/S 505

Las Vegas, NV 89193-8518

702-295-3521

U.S. Department of Energy

Office of Scientific and Technical Information

P.O. Box 62

Oak Ridge, TN 37831-0062

865-576-8401

Southern Nevada Public Reading Facility

c/o Nuclear Testing Archive

P.O. Box 98521, M/S 400

Las Vegas, NV 89193-8521 $\underline{\text { Copies }}$

1 (Uncontrolled)

1 (Uncontrolled, electronic copy)

2 (Uncontrolled, electronic copies) 
This page intentionally left blank 


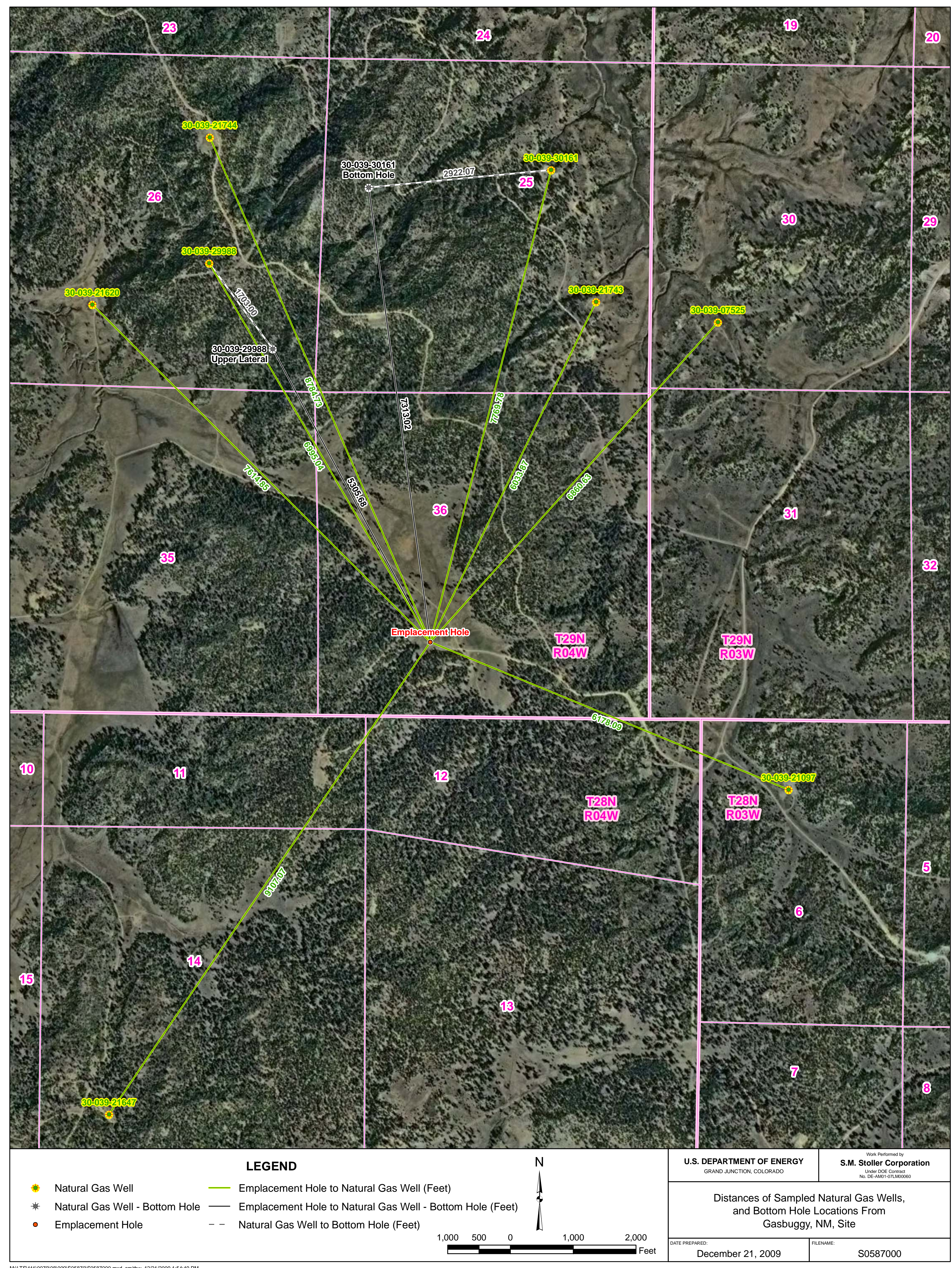

